\title{
Synthetic Hexaploid Wheat 'Synthetic 45': A Novel Source for Leaf Rust Resistance Gene in Wheat
}

\author{
Prem Chand Gyani ${ }^{1 *}$, Pooja Yadav ${ }^{2}$ and J. B. Sharma ${ }^{1}$ \\ ${ }^{1}$ Division of Genetics, ICAR-Indian Agricultural Research Institute, New Delhi 110012, India \\ ${ }^{2}$ Department of Genetics and Plant Breeding, RVSKVV, Gwalior 474002, India \\ *Corresponding author
}

\section{A B S T R A C T}

\begin{tabular}{|l|}
\hline Key w o r d s \\
$\begin{array}{l}\text { Wheat, SHWs, leaf } \\
\text { rust, resistance, } \\
\text { disease, wheat rust }\end{array}$ \\
\hline Article Info \\
\hline $\begin{array}{l}\text { Accepted: } \\
\text { 05 February } 2020 \\
\text { Available Online: } \\
\text { 10 March } 2020\end{array}$ \\
\hline \hline
\end{tabular}

Wheat rusts (Leaf rust, Stem rust and Stripe rust) continue to pose a serious threat by inflicting losses in different parts of world. Leaf rust caused by Puccinia triticina Eriks. is the most common rust disease of wheat (Triticum aestivum L.) and is widespread in India and posses a major threat to the wheat production of the country. Depending upon the severity and duration of infection, the losses may reach up to $50 \%$ of the yield. CIMMYT has developed a series of synthetic hexaploid wheat (SHW) by incorporating D genome donor Triticum tauschii in T. durum cultivars. In the present study one of these SHWs, Synthetic 45 was investigated for effectivity of leaf rust resistance. Characterization of leaf rust resistance in Synthetic 45 by multipathotype testing showed high degree of broad spectrum resistance at seedling stage to diverse 15 pathotypes of leaf rust pathogen in India.

\section{Introduction}

Wheat (Triticum spp.) is one of the most important food crops which accounts for 19 per cent of the total cereal crop production in the world and is a staple food for 30 per cent of the world population (Eversole et al., 2014). In 2018, world production of wheat was 735.17 million tonnes from an area of 214.79 million hectares. The global wheat productivity amount to $3.42 \mathrm{t} / \mathrm{ha}$ (Source: FAOSTAT, 2018). In India, wheat is the second most important cereal crop after rice and plays an important role in food and nutritional security.

India with acreage of 29.58 million hectares (Source: DES, 2015) and production of 99.70 million tonnes (Source: DES,2018) is the second largest wheat producing country after china in the world with average productivity of 3.371 tonnes/hectare (Source: DES, 2018). Major wheat growing states of India are Uttar Pradesh, Punjab, Haryana, Madhya Pradesh, 
Rajasthan, Gujarat and Bihar. However, to keep pace with the ever growing population India will need increased production.

Wheat rusts (Leaf rust, Stem rust and Stripe rust) continue to pose a serious threat by inflicting losses in different parts of world. Leaf rust caused by Puccinia triticina Eriks. is the most common rust disease of wheat (Triticum aestivum L.) and is widespread in India and posses a major threat to the wheat production of the country.

Depending upon the severity and duration of infection, the losses may reach up to 50 Leaf rust of wheat caused by Puccinia triticina Rob.Ex Desm. f. sp. tritici Eriks (syn. Puccinia recondita f. sp. tritici) is found nearly wherever wheat is grown, and is the most regularly occurring of the three rusts (Chester, 1946; Roelfs, 1995). Leaf rust has potential to cause losses of up to 50 per cent and because of its more frequent and widespread occurrence, leaf rust probably results in greater total annual losses worldwide than stem and stripe rusts (HuertaEspino et al., 2011.

To overcome the problem geneticists are searching for new sources of resistance particularly from related species of wheat. Goat grass (Triticum tauschii), the D-genome donor in bread wheat a relatively untapped germplasm pool was used in production of synthetic hexaploid wheats (SHWs) at CIMMYT. The SHWsthus produced, possess potential variability for morpho-agronomic traits as well as resistance/ tolerance to biotic/abiotic stresses (Valkoun et al., 1990, Cox et.al., 1994).

Goat grass [(Trticum tauschii (Coss.) Schmal, formerly Aegilops squarrosa L.)] constitute a relatively untapped germplasm pool for broadening the genetic base of common hexaploid wheat. This diploid species, the donor of the D-genome in wheat was evaluated by several workers and it has reported to be a source of resistance to biotic and and abiotic stresses such as Karnal bunt (Tilletia indica), scab (Fusarium graminearum), spot blotch (Helminthosporium sativum syn. Bipolaris sorokiniana), leaf rust (Puccinia recondita), stripe rust ( $P$. striformis), cold temperature, salinity and drought.

The present investigation was undertaken on Synthetic 45 to obtain information on assessment of its resistance against array of leaf rust pathotypes. It shows the potential of synthetic 45 as a novel stock for obtaining leaf rust resistance gene. In future the leaf rust resistance gene can be incorporated in the cultivated varieties of wheat.

\section{Materials and Methods}

\section{Host material}

The seeds of following plant material were available in the Division of Genetics, Indian Agricultural Research Institute, New Delhi.

Synthetic 45 was one of the many synthetic hexaploid wheat lines derived from the crosses between different Triticum turgidum var. durum lines as female parents and different accessions of $T$. tauschii in wide hybridization programme at International Maize and Wheat Improvement Center (CIMMYT).

Wheat cultivar Agra Local was used as a susceptible parent in crosses with Synthetic 45 as well as susceptible check in this study. Agra Local, a tall wheat cultivar was grown locally during the early part of this century in Western Uttar Pradesh. Because of its high degree of susceptibility to all the Indian pathotypes of leaf rust pathogen at seedling as well as at adult stage of plant growth, it was used as a susceptible parent for inheritance 
studies and for maintaining rust cultures throughout the country since1929 (Mehta,1929).

\section{Pathogen}

Pure and viable urediospore inoculum of fifteen individual pathotypes of leaf rust pathogen Puccinia triticina Eriks. used in the study was obtained from IIWBR, Regional Station, Flowerdale, Shimla. All the twenty pathotypes of leaf rust were used in multipathotype tests. These pathotypes along with their binomial designation and avirulence/virulence formulae based on Nagarajan et al., (1983) are given in Table 1. However, in the present study only old designations of the pathotypes which are still in more use are mentioned in the text. Out of these fifteen pathotype, pathotype 77-5 was selected for inheritance studies, because pathotypes 77-5 is the most virulent and prevalent pathotype in natural flora of Puccinia triticina pathogen present in the India.

\section{Methods}

\section{Multiplication of rust inoculums}

Urediospore inoculum of individual pathotypes of leaf rust (Puccinia triticina) procured form IIWBR, Regional Station, Flowerdale, Shimla, was multiplied following the procedure described by Joshi et al., (1988) in glasshouse available at Division of Genetics, IARI, New Delhi.

For sowing of susceptible host genotype Agra Local 4" plastic pots were filled with mixture of garden soil and farm yard manure (FYM) in 5:1 ratio. After filling $2 / 3 \mathrm{rd}$ of the pot, seeds were sown at the leveled surface and topped up by soil mix. Adequate irrigation was provided to facilitate the uniform germination. Ten days old seedlings were inoculated by applying rust inoculum mixed with non-toxic talcum powder with the help of lanceolate needle. After inoculation seedlings were sprayed with enough water to leave dew drops on the leaves and kept in moist humid chambers. After 48 hours of incubation, seedlings were shifted to glass house benches at the temperature range of 20280C for sporulation. After 15 days on disease development, multiplied inoculum was collected at periodic interval on a butter paper by gently tapping the infected seedlings. Packets of collected urediospore inoculums were left at room temperature for a day and then kept in desiccators in the refrigerator.

\section{Screening of test material against rust}

For multipathotype test seedlings of resistant parent 'Synthetic 45 and susceptible parent "Agra Local' were raised in 4" pots . The multiplied urediospores of individual pathotypes were sprayed on 10 days old seedlings as a suspension in water along with a drop of Tween 20 (Polysorbate 20), a surfactant, and kept in humidity chamber for 48 hours before shifting to glass house benches.

Infection types were recorded after 12 days of inoculation following the Stakman et al., (1962) 0-4 scale classification. The infection type $0, ;, 1$ and 2 were classified as resistant reaction while infection types 3 and 4 were classified as susceptible.

\section{Results and Discussion}

Genetic analysis of genes controlling resistance in a particular genetic background is important for effective utilization of the resistant stocks in breeding programmes. The present investigation was undertaken to assess the resistance in synthetic hexaploid wheat line 'Synthetic 45' against diverse pathotypes of leaf rust pathogen. 
Table.1 Infection types on Synthetic 45 and Agra Local against 15 pathotypes of Puccinia triticina when tested at seedling stage of plant growth at mean temperature range $20-28^{\circ} \mathrm{C}$

\begin{tabular}{|c|c|c|c|c|}
\hline \multirow[t]{2}{*}{ S.No } & \multicolumn{2}{|c|}{$\begin{array}{l}\text { Pathotype } \\
\text { designation }\end{array}$} & \multirow[t]{2}{*}{ Synthetic 45} & \multirow[t]{2}{*}{ Agra Loca } \\
\hline & Old & New & & \\
\hline 1 & $12 \mathrm{~A}$ & $5 \mathrm{R} 13$ & $; \mathbf{1}^{-}$ & $3^{+}$ \\
\hline 2 & $12-1$ & $5 \mathrm{R} 37$ & $; \mathbf{1}^{\mathbf{1}}$ & $33^{+}$ \\
\hline 3 & $12-7$ & 93R 45 & ;1 & $33^{+}$ \\
\hline 4 & $12-8$ & $49 \mathrm{R} 45$ & $; \mathbf{1}^{\mathbf{1}}$ & $3^{+}$ \\
\hline 5 & $12-9$ & 93R37 & $; \mathbf{1}^{=}$ & $3^{+}$ \\
\hline 6 & $77-1$ & 109R63 & $; 1^{-}$ & $33^{+}$ \\
\hline 7 & $77-2$ & 109R31-1 & $; 1^{=}$ & $3^{+}$ \\
\hline 8 & $77-5$ & 121R63-1 & $; \mathbf{1}^{-}$ & $3^{+}$ \\
\hline 9 & $77-8$ & 253R31 & ;1 & $3^{+}$ \\
\hline 10 & $77-10$ & 377R60-1 & 1 & $33^{+}$ \\
\hline 11 & $104-1$ & 21R31-1 & $; \mathbf{1}^{=}$ & $3^{+}$ \\
\hline 12 & $104-2$ & 21R55 & $; \mathbf{1}^{=\mathrm{N}}$ & $3^{+}$ \\
\hline 13 & $104-3$ & 21R63 & $; 1^{=}$ & $3^{+}$ \\
\hline 14 & $104-4$ & 21R57 & ;1= & $3^{+}$ \\
\hline 15 & $107-1$ & $45 \mathrm{R} 35$ & ; & $3^{+}$ \\
\hline
\end{tabular}

\section{Multipathotype tests}

Resistant stock Synthetic 45 along with susceptible variety Agra Local was screened against 15 pathotypes of leaf rust pathogen (Puccinia triticina) at seedling stage under glass house conditions and against two most predominant pathotypes $77-5$ and $104-2$ of Indian leaf rust flora at adult stage of plant growth under field conditions.

\section{Seedling Tests}

Infection types (IT) produced on all the three test lines i.e. Synthetic 45 and Agra Local are presented in Table 1. Synthetic 45 expressed resistant reaction against all the 20 pathotypes with infection type ranging from IT ';' to IT ' 1 '. In contrast, Agra were susceptible (ITs ' $33+$ ' to ' $3+$ ') to all the 15 pathotypes used in the study. Results indicate that leaf rust resistance of Synthetic 45 is broad spectrum with effectiveness to all the 15 pathotypes of leaf rust pathogen tested at seedling stage.

\section{Acknowledgement}

The first author gratefully acknowledges the Indian Council of Agricultural Research (ICAR) for providing financial assistance for the study. 


\section{References}

Bhardwaj, S. C., Prashar, M., Jain, S. K., Kumar, S. Sharma, Y. P., Sivasamy, M. and Kalappannavar, I. K. (2010a). Virulence on $\operatorname{Lr} 28$ in wheat and its relation to prevalent pathotypes in India. Cereal Res. Commun. 38: 83-89.

Bhardwaj, S. C., Prashar, M., Jain, S. K., Kumar, S. and Sharma, Y. P. (2010b). Physiologic specialization of Pucciniatriticina on wheat (Triticum species) in India. Indian J. Agric. Sci. 80: 805-811.

Bhardwaj, S. C., Prashar, M., Jain, S. K., Kumar, S., Datta, D. (2010c). Adult plant resistance in some Indian wheat genotypes and postulation of leaf rust resistance genes. IndianPhytopathol.63: 174-180.

Bhardwaj, S. C., Prashar, M., Kumar, S., Jain, S. K. and Datta, D. (2005). Lr19 resistance in wheat becomes susceptible to Pucciniatriticina in India. Plant Dis. 89: 1360.

Bhardwaj, S. C., Prashar, M., Kumar, S., Jain, S. K., Sharma, Y. P. and Kalappanavar, I. K. (2011). Two new pathotypes 125R28 and 93R37 of Pucciniatriticina on wheat from India and sources of resistance. IndianPhytopathol. 64 (3): 240-242.

Cox, T. S., Raupp, W. J., \& Gill, B. S. (1994). Leaf Rust-Persistance Genes Lr41, Lr42, and Lr43 Transferred from Triticum tauschii to Common Wheat. Crop science, 34(2), 339-342.

Czembor, P.C., M. Radecka-Janusik, A. Pietrusińska, and H.J. Czembor. 2008. Proceeding of the 11th International Wheat Genetics Symposium Aug 24-29, 2008, Brisbane, QLD, Australia, Ed. R. Appel, R. Eastwood, E. Lagudar, P. Langridge, M. Mackay, L. McIntyre, P. Sharp. 739-740 (824pp).
Joshi, L.M., Singh, D.V. and Srivastava, K.D. (1988). Manual of wheat diseases. Malhotra Publication House, New Delhi, 75 pp.

Kosambi, D.D. (1944). The estimation of map distances from recombination values. Ann. Eugen. 12: 172-175.

Lander, E.S., Green, P., Abrahamson, J., Barlow, A., Daly, M.J., Lincoln, S.E. and Newburg, L. (1987). MAPMAKER: an interactive computer package for constructing primary genetic linkage maps of experimental and natural populations. Genomics. 1: 174-181.

Michelmore, R.W., Paran, I. and Kesseli, R.V. (1991). Identification of markers linked to disease-resistance genes by bulked segregant analysis: a rapid method to detect markers in specific genomic.regions by using segregating populations. Proceedings of the National Academy of Sciences, USA. 88: 9828-9832.

Murray, M.G. and Thompson, W.F. (1980). Rapid isolation of high molecular weight plant DNA. Nucleic Acids Research. 8(19): 4321-4325.

Nayar, S.K., Jain, K., Prashar, M., Bhardwaj, S.C., Kumar, S. and Menon, M.K. (2003). Appearance of new pathotype of Puccinia recondita f. sp. tritici virulent on Lr9 in India. Indian Phytopathol. 56: 196-198

Stakman, E.C., Stewart, D.M. and Loegering, W.Q. (1962). Identification of physiologic races of Puccinia graminis var. tritici. Agricultural Research Service E617. (United States Department of Agriculture: Washington DC.).

Valkoun, J., J. Dostal, and D. Kučerová. "Triticum $\times$ Aegilops hybrids through embryo culture." Wheat. Springer Berlin Heidelberg, 1990. 152-166. 


\section{How to cite this article:}

Prem Chand Gyani, Pooja Yadav and Sharma. J. B. 2020. Synthetic Hexaploid Wheat 'Synthetic 45': A Novel Source for Leaf Rust Resistance Gene in Wheat. Int.J.Curr.Microbiol.App.Sci. 9(03): 1103-1108. doi: https://doi.org/10.20546/ijcmas.2020.903.129 